\title{
ANÁLISE CRÍTICA DO ARTIGO 20 DA LEI N. 8.429/1992
}

$\underline{\text { Samara Fernandes da Cruz Aguiar }{ }^{1}}$

Artigo recebido em: 24/01/2019

Artigo aceito em: 07/03/2019

\section{Resumo}

O objetivo deste artigo é demonstrar da CR/88), bem como dos efeitos a viabilidade jurídica de percepçáo provocados na esfera patrimonial de remuneração proporcional ao desse, sem que isso viole o Princípio tempo de serviço para servidores (ou Postulado) da Razoabilidade. Em públicos afastados cautelarmente arremate, demonstra-se a viabilidade de da função quando a medida se fizer interpretar o parágrafo único do artigo necessária à instrução processual, nos 20 nessa mesma linha de intelecção. termos do art. 20, parágrafo único, da Lei n. 8.429/1992. Para tanto, propóe-se o cotejo entre o instituto da disponibilidade e do afastamento cautelar. Traça-se uma breve análise da situação do servidor público posto em disponibilidade (art. 41, $\$ 3^{\circ}$, dade.

1 Especialista em Direito Constitucional pela Faculdade Anhanguera. Bacharel em Direito pelo Centro Universitário UNA. Estagiária de pós-graduação lato sensu no Ministério Público de Minas Gerais. E-mail: samaracfernandes@ gmail.com 


\section{CRITICAL ANALYSIS OF ARTICLE 20 OF}

\section{LAW N. 8.429/1992}

\section{Abstract}

The purpose of this article is to $\mathbb{S} 3$, of $(R / 88)$, as well as of the effects demonstrate the legal feasibility of caused in the patrimonial sphere of this receiving remuneration proportional to one, without violating the Principle the length of service for public servants (or Postulate) of the Reasonableness. In precautionary leave from the function when the measure becomes necessary to the procedural instruction, under the terms of art. 20, sole paragraph, of Lawn. 8.429/1992. In order to do so, we propose a comparison between the institute of availability and precautionary leave. A brief analysis of the situation of the public servant put into availability (article 41, closing, it is demonstrated the feasibility of interpreting the sole paragraph of article 20 in the same line of intellection.

Keywords: availability; Principle of Reasonability; Law of Administrative Improbity; precautionary removal; partial remuneration; viability.

\section{Introdução}

O parágrafo único do artigo 20 da Lei de Improbidade Administrativa (Lei n. 8.429, de 4 de junho de 1992) avaliza a possibilidade de afastamento do agente público do exercício do cargo, emprego ou função, sem prejuízo da remuneração, quando a medida se fizer necessária à instrução processual.

O dispositivo legal, ao permitir o afastamento do servidor público de suas funções, tem por escopo garantir o bom andamento da instrução processual na apuraçấo de eventuais atos ímprobos. Trata-se de instrumento de natureza processual, com nítida feição cautelar, sem qualquer traço sancionatório. De qualquer maneira, a norma deve ser avocada com prudência e somente casos de especial necessidade.

A literalidade do dispositivo dá nota de que o afastamento se dá "sem prejuízo da remuneração", de modo que a interpretação comumente atribuída é que, nas hipóteses de aplicação, os vencimentos auferidos pelo agente público são concedidos em sua integralidade, como se estivesse no exercício regular da função pública.

Ocorre que as mudanças sociais e as alteraçôes no texto constitucional ao longo dos anos solaparam projeção razoavelmente distinta da literalidade do dispositivo. A bem da verdade, descortinou-se cenário suscetível de afastar a exegese atribuída até entáo sem questionamentos. 
Cumpre-nos aduzir, nesse contexto, a situação do servidor público civil posto em disponibilidade nos termos do artigo 41, parágrafo $3^{\circ}$, da Constituição da República de 1988. Um breve cotejo entre esses dois institutos, quais sejam, o afastamento cautelar (art. 20, $\$$ único, da Lei n. 8.429/1992) e a disponibilidade (art. $41, \S 3^{\circ}$, da CR/88) é um bom começo para introduzir a discussão no meio jurídico.

Registre-se que não há pretensão, nesta modesta publicação, de esgotar o tema, mas tão somente de provocar a análise crítica do dispositivo legal, considerando sobretudo a atual performance do Legislativo Brasileiro no intento de conferir à Lei n. 8.429/1992 maior contemporaneidade e efetividade (a título de exemplo, vide, entre tantos outros, os Projetos de Lei n. 3.636/2015, 10.887/2018 e 10.106/2018, em trâmite na Câmara dos Deputados, e os Projetos de Lei n. 71/2017, 187/2018 e 380/2018, todos em curso perante o Senado Federal).

É com essa ótica que se passa à análise do tema, estabelecendo um breve cotejo entre os institutos da disponibilidade e do afastamento cautelar.

\section{Do Instituto da Disponibilidade: histórico constitucional e breves reflexóes críticas}

A Constituição da República de 1988 dispóe que "extinto o cargo ou declarada sua desnecessidade, o servidor ficará em disponibilidade, com remuneração proporcional ao tempo de serviço, até o seu adequado aproveitamento em outro cargo" (artigo 41, $\$ 3^{\circ}, \mathrm{CR} / 88$ ). A disponibilidade é instituto próprio do Direito Administrativo, afeto ao estudo dos direitos e garantias dos agentes públicos, aplicável aos servidores ocupantes de cargos de provimento efetivo.

De acordo com José dos Santos Carvalho Filho, a disponibilidade é a "situação funcional na qual o servidor passa à inatividade em virtude da extinção de seu cargo ou da declaração de sua desnecessidade" (2013, p. 733). Para Maria Sylvia Zanella di Pietro, "a disponibilidade é a garantia de inatividade remunerada, assegurada ao servidor estável, em caso de ser extinto o cargo ou declarada sua desnecessidade" (2013, p. 658).

Com efeito, o instituto da disponibilidade é revestido de envergadura constitucional há muitos anos. Embora omissas as três primeiras Constituiçóes (Constituição do Império de 1824, Constituição da República de 1891 e Constituição da República de 1934), depreende-se que desde a Carta de 1937 a matéria é expressamente alocada no texto constitucional. Naquela época, era a dicção da lei maior: 
Art. 157. Poderá ser posto em disponibilidade, com vencimentos proporcionais ao tempo de serviço, desde que não caiba no caso a pena de exoneração, o funcionário civil que estiver no gozo das garantias de estabilidade, se, a juízo de uma comissão disciplinar nomeada pelo Ministro ou chefe de serviço, o seu afastamento do exercício for considerado de conveniência ou de interesse público (BRASIL, 1937, grifo nosso).

Constata-se que a disponibilidade, naquela oportunidade, era eivada de caráter eminentemente sancionatório, assim como a exoneração, que igualmente fora empregada para fins de punição administrativa. A Constituição da República de 1946, de outro modo, passou a disciplinar a disponibilidade da seguinte maneira:

Art. 189. Os funcionários públicos perderão o cargo:

I - quando vitalícios, somente em virtude de sentença judiciária;

II - quando estáveis, no caso do número anterior, no de se extinguir o cargo ou no de serem demitidos mediante processo administrativo em que se lhes tenha assegurado ampla defesa.

Parágrafo único - Extinguindo-se o cargo, o funcionário estável ficará em disponibilidade remunerada até o seu obrigatório aproveitamento em outro cargo de natureza e vencimentos compatíveis com o que ocupava. (BRASIL, 1946, grifo nosso).

É a partir desse momento que a concepção garantista do instituto foi instituída em nosso Ordenamento Jurídico. A índole protetora do preceito foi ratificada pela Constituição de 1967, que dispunha:

Art. 99. São estáveis, após dois anos, os funcionários, quando nomeados por concurso.

$\$ 1^{\circ}$ - Ninguém pode ser efetivado ou adquirir estabilidade, como funcionário, se não prestar concurso público.

$\$ 2^{\circ}$ - Extinto o cargo, o funcionário estável ficará em disponibilidade remunerada, com vencimentos integrais, até o seu obrigatório aproveitamento em cargo equivalente (BRASIL, 1967, grifo nosso).

Com o advento do Ato Complementar n. 40, de 30 de dezembro de 1968, o parágrafo $\$ 2^{\circ}$ do artigo 99 da CR/67 foi alterado, passando a prescrever que "extinto o cargo ou declarada pelo poder executivo a sua desnecessidade, o funcionário estável ficará em disponibilidade remunerada, com proventos 
proporcionais ao tempo de serviço". A Emenda Constitucional n. 1/1969 (tida por alguns como "Constituiçáo de 1969") reproduziu o preceito ipsis litteris:

Emenda Constitucional n. 1, de 17 de outubro de 1969 - Art. 100. Serão estáveis, após dois anos de exercício, os funcionários nomeados por concurso.

Parágrafo único. Extinto o cargo ou declarada pelo Poder Executivo a sua desnecessidade, o funcionário estável ficará em disponibilidade remunerada, com vencimentos proporcionais ao tempo de serviço (BRASIL, 1969, grifo nosso).

Promulgada a Constituição da República de 1988, a disponibilidade passou a ser disciplinada pelo $\$ 3^{\circ}$ do artigo 41 , cuja redação originária era a seguinte:

Art. 41. São estáveis, após dois anos de efetivo exercício, os servidores nomeados em virtude de concurso público. [...].

$\$ 3^{\circ}$ Extinto o cargo ou declarada sua desnecessidade, o servidor estável ficará em disponibilidade remunerada, até seu adequado aproveitamento em outro cargo (BRASIL, 1988, grifo nosso).

Quis a norma constitucional, a exemplo do que fizera o constituinte em 1946, manter-se neutra quanto ao valor dos proventos a serem recebidos pelo servidor estável em casos de extinçáo ou de declaraçáo de desnecessidade do cargo. Perante a proposital omissão no texto constitucional, bem como diante da notória natureza protetiva do instituto, surgiram vozes defendendo, de um lado, a percepçáo proporcional dos vencimentos e, de outro, o recebimento integral.

Nesse contexto, em 20 de junho de 1990, dois anos depois de promulgado o texto constitucional, o Supremo Tribunal Federal foi provocado a enfrentar o tema. Isso porque em 15 de junho de 1990 fora publicado o Decreto n. 99.300, cujo escopo é a regulamentação os proventos dos servidores postos em disponibilidade. Eis o teor dos artigos inaugurais:

Art. $1^{\circ}$ Os proventos dos servidores estáveis, cujos cargos ou empregos forem extintos ou declarados desnecessários, serão calculados proporcionalmente ao tempo de serviço público, com base nos registros constantes dos respectivos assentamentos individuais.

Art. $2^{\circ}$ No cálculo do valor dos proventos a que têm direito os servidores em disponibilidade serão incluídos exclusivamente:

a) o vencimento do cargo ou salário do emprego; 
b) o adicional por tempo de serviço;

c) os quintos previstos no art. $2^{\circ}$ da Lei n. 6.732, de 4 de dezembro de 1979;

d) o salário-família;

e) as vantagens pessoais nominalmente identificadas.

Parágrafo único. Para efeito de cálculo dos proventos proporcionais serão considerados como base os seguintes limites de tempo de serviço fixados para a aposentadoria voluntária:

a) aos trinta e cinco anos de serviço, se homem, e aos trinta, se mulher;

b) aos trinta anos de efetivo exercício em funçôes de magistério, se professor, e vinte e cinco, se professora;

c) nos prazos especiais de proventos integrais regulados em lei (BRASIL, 1990, grifo nosso).

O Partido Democrático Trabalhista - PDT recorreu à Corte para pedir a declaração de inconstitucionalidade de todo o Decreto ou, subsidiariamente, do artigo $1^{\circ}$ e do parágrafo único do artigo $2^{\circ}$. Em agosto de 1991, o Tribunal Pleno, por maioria de votos, julgou procedente o pedido formulado na Açáo Direta de Inconstitucionalidade n. 313/DF, declarando a inconstitucionalidade dos arts. $1^{\circ}$ e $2^{\circ}$ do Decreto n. 99.300, de 15.6.1990.

Assentou, em síntese, que a fixação de vencimentos proporcionais não era compatível com a índole garantista do $₫ 3^{\circ}$ do artigo 41 da CR/88:

CONSTITUCIONAL. Servidor em disponibilidade. Vencimentos, Súmula 358 STF. Segundo a Constituição de 1988, também era assim em 46 e 67, disponibilidade não e puniçâo. Disponibilidade e aposentadoria. Vencimentos e proventos. Conceitos distintos: vencimentos de servidor em atividade, ainda que em disponibilidade, e proventos da inatividade. Linguagem legal e sumular. Irredutibilidade de vencimentos e de proventos. Dec. 99.300/90. Fixação de vencimentos proporcionais ao servidor em disponibilidade. Inconstitucionalidade em face do art. 41, par. 3., CF. Ação julgada procedente.

STF. ADI 313. Relator Min. Paulo Brossard. Tribunal Pleno. Julgado em 21/08/1991. DJ 30/04/1992.

Com esse julgamento, a Suprema Corte reafirmou sua jurisprudência consolidada, ratificando o verbete n. 358, editado nos idos de 1963, segundo o qual "o servidor público em disponibilidade tem direito aos vencimentos integrais do cargo". 
Cumpre aduzir, no entanto, que a Emenda Constitucional n. 19, de 04 de junho de 1998, modificou sensivelmente o tratamento constitucional atribuído ao tema.

Inicialmente, é imperioso recordar que a Emenda Constitucional n. 19/98 pretendeu revigorar a Administração Pública, reestruturando o Estado e redefinindo sua forma de atuação, a fim superar a crise e a prolongada estagnação econômica que experimentava o Brasil naquela oportunidade. A Emenda pautou-se no fortalecimento da capacidade de gestão e engajou esforços para a retomada do desenvolvimento econômico, com impactos positivos sobre a ação governamental e sobre a sociedade.

De acordo com sua exposição de motivos, “a revisão de dispositivos constitucionais não esgota a reforma administrativa, mas representa etapa imprescindível ao seu sucesso, promovendo a atualização de normas”. Especificamente quanto à disponibilidade:

EMENDA CONSTITUCIONAL N. 19, DE 04 DE JUNHO DE 1998 (Exposição De Motivos Interministerial n. 49, de 18 de agosto de 1995) - O instituto da disponibilidade remunerada foi revisto, prevendo-se expressamente a percepção de remuneração proporcional ao tempo de serviço, até o reaproveitamento do servidor em cargo de mesma natureza atributiva. A readequação proposta visa reforçar a sua viabilidade como instrumento destinado a facilitar processos de reorganização administrativa, podendo ser empregado alternativamente ao desligamento do servidor (BRASIL, 1998).

Diante disso, a redação conferida pela Emenda (e que permanece em vigor até os dias atuais) ao parágrafo $3^{\circ}$ do artigo 41 é esta:

EMENDA CONSTITUCIONAL N. 19, DE 04 DE JUNHO DE 1998

As Mesas da Câmara dos Deputados e do Senado Federal, nos termos do $₫ 3^{\circ}$ do art. 60 da Constituição Federal, promulgam esta Emenda ao texto constitucional: [...].

Art. $6^{\circ} \mathrm{O}$ art. 41 da Constituição Federal passa a vigorar com a seguinte redação:

Art. 41. São estáveis após três anos de efetivo exercício os servidores nomeados para cargo de provimento efetivo em virtude de concurso público. [...].

$\$ 3^{\circ}$ Extinto o cargo ou declarada a sua desnecessidade, o servidor estável ficará em disponibilidade, com remuneração 
proporcional ao tempo de serviço, até seu adequado aproveitamento em outro cargo (BRASIL, 1998, grifo nosso).

Nesse aspecto, a Emenda Constitucional n. 19/98 revelou-se numa bem-sucedida investida de reversáo jurisprudencial, ou, em outras palavras, de superação legislativa da jurisprudência. O fato é que, a par de tamanho revertério no texto constitucional, o Supremo Tribunal Federal foi compelido a rever seu posicionamento, passando a admitir a percepção de remuneração proporcional:

AÇÃO DIRETA DE INCONSTITUCIONALIDADE. ARTIGO 90, $\$ 3^{\circ}$, DA CONSTITUIÇÃO DO ESTADO DO RIO DE JANEIRO. DISPONIBILIDADE REMUNERADA DOS SERVIDORES PÚBLICOS. EDIÇÃO DA EC N. 19/98. SUBSTANCIAL ALTERAÇÃO DO PARÂMETRO DE CONTROLE. ARTIGO 41, $\$ 3^{\circ}$, DA CONSTITUIÇÃO FEDERAL. NÃO OCORRÊNCIA DE PREJUÍZO. FIXAÇÃO DE PRAZO PARA APROVEITAMENTO DO SERVIDOR. INCONSTITUCIONALIDADE. INTEGRALIDADE DA REMUNERAÇÃO. NÁO RECEPÇÃO PELA EC N. 19/98.

1. A Emenda Constitucional n. 19/98 alterou substancialmente parte do art. $41, \$ 3^{\circ}$, da Constituição Federal, o qual figura como paradigma de controle na ação. Necessidade de adoção de dois juízos subsequentes pelo Tribunal. O primeiro entre o preceito impugnado e o texto constitucional vigente na propositura da ação, com o fim de se averiguar a existência de compatibilidade entre ambos (juízo de constitucionalidade). Já o segundo entre o dispositivo questionado e o parâmetro alterado (atualmente em vigor), com o escopo de se atestar sua eventual recepçáo pelo texto constitucional superveniente.

2. A imposição do prazo de um ano para aproveitamento do servidor em disponibilidade ofende materialmente a Carta Federal, pois consiste em obrigação criada pelo Poder Legislativo que não decorre direta ou indiretamente dos pressupostos essenciais à aplicaçấo do instituto da disponibilidade definidos na Constituição da República (art. 41, $3^{\circ}$ ), e, principalmente, porque náo condiz com o postulado da independência dos Poderes instituídos, ainda que em sede do primeiro exercício do poder constituinte decorrente.

3. $\mathrm{O}$ art. $41, \S 3^{\circ}$, da Constituiçáo Federal, na sua redaçáo originária, era silente em relaçáo ao quantum da remuneraçáo 
que seria devida ao servidor posto em disponibilidade. Esse vácuo normativo até entâo existente autorizava os estados a legislar sobre a matéria, assegurando a integralidade remuneratória aos seus servidores. Contudo, a modificaçáo trazida pela EC 19/98 suplantou a previsáo contida na Carta estadual, pois passou a determinar, expressamente, que a remuneraçáo do servidor em disponibilidade seria proporcional ao tempo de serviço. 4. Açáo direta julgada parcialmente procedente.

STF. ADI 239, Relator Min. Dias Toffoli. Tribunal Pleno. Julgado em 19/02/2014. Publicação 30/10/2014 (grifo nosso).

É a disponibilidade remunerada, a teor da atual Constituição da República, garantia especial do servidor público, corolário da harmoniosa ponderaçáo entre o interesse público e as garantias constitucionais conferidas a esse agente, face a sua fundamentalidade. Constitui-se em manifesta prerrogativa, conforme lecionam Celso Antônio Bandeira de Mello e Diogenes Gasparini, respectivamente:

A disponibilidade é um direito que a Constituição confere ao servidor público civil estável, caso seu cargo venha a ser extinto ou declarado desnecessário ( $\$ 3^{\circ}$ do art. 41 ), ou ainda quando, em virtude de reintegraçáo de outrem, seja desalojado do cargo que ocupava sem ter um cargo de origem para regressar a ele (art. 41, $\$ 2^{\circ}$, precitado) (MELLO, 2011, p. 292, grifo nosso).

Nesses dois parágrafos está constitucionalmente instituída e regulada a disponibilidade, como garantia do servidor estável. Pode ser definida como a garantia constitucionalmente assegurada ao servidor estável, que impede seu desligamento a Administração Pública quando extinto o cargo, declarada sua desnecessidade ou reintegrado seu titular, percebendo, enquanto durar a disponibilidade, proventos proporcionais ao tempo de serviço. Não é, assim, pena (embora já tenha sido, na vigência da Carta de 1937 e na do Ato Institucional n. 5/68) aplicável ao servidor, nem tampouco instrumento de perseguição ou favoritismo de integrantes dessa espécie de agente público. Muito menos é modalidade de aposentadoria. É direito, repisa-se, do servidor estável, utilizável em razão do interesse público (GASPARINI, 2011, p. 276, grifo nosso). 
Assim sendo, cumpre registrar que há dois pressupostos elencados pela Constituição Cidadã para o advento da disponibilidade: (i) extinção do cargo público originalmente ocupado pelo servidor, por meio de lei ou, excepcionalmente, por Decreto Autônomo, quando vagos (artigo 84, inciso VI, "b", CR/88); ou (ii) declaração da desnecessidade do cargo, por ato administrativo declaratório. Tais ocorrências podem derivar de eventuais demissōes, exoneraçóes ou até mesmo promoçóes que, desfeitas, implicam ao retorno do status quo ante.

Examinando sob essa ótica, perceba-se, o servidor público estável é afastado de sua atividade por interesse da Administração Pública. A Constituição não adentra ao mérito do bom ou mau desempenho das funçōes, limitando-se a relacionar como requisitos atos administrativos (declaração da extinção ou desnecessidade do cargo público). Nesse ínterim, até que sobrevenha outra forma de provimento, o agente público será posto em disponibilidade e auferirá a título de vencimentos quantum proporcional ao tempo de serviço.

Não custa salientar, novamente, que a hodierna conjuntura da disponibilidade não preserva em si qualquer traço sancionatório. A percepção de remuneração proporcional ao tempo de serviço não significa a aplicação de penalidade, antes, como visto, a disponibilidade é direito do servidor. Bem por isso a modalidade de disponibilidade em testilha se difere da chamada "disponibilidade punitiva", como bem pontifica José dos Santos Carvalho Filho:

É oportuno salientar, desde logo, que o instituto em foco não se confunde com a disponibilidade punitiva, que conforme indica a própria expressáo, estampa modalidade de sançáo funcional, e nada tem a ver com a extinçáo ou desnecessidade do cargo. É o caso da disponibilidade punitiva de magistrados, prevista no art. 93, inc. VIII, da CF, pela qual o juiz fica afastado compulsoriamente de seu cargo pelo voto da maioria absoluta do respectivo tribunal ou do Conselho Nacional de Justiça, percebendo subsídios proporcionais ao tempo de serviço. Idêntica sanção, aliás, aplica-se também aos membros do Ministério Público, como prevê o art. 130-A, $\$ 2^{\circ}$, III, da CF introduzido pela EC 45/2004 (CARVALHO FILHO, 2013, p. 733, grifo nosso).

Por conseguinte, ao contrário do que se imagina, é possível, ainda que hipoteticamente, que o mais eficiente e prestativo servidor seja posto em disponibilidade, pois o que prevalece para esse fim é o interesse público quanto à manutenção do cargo.

Como regra, o servidor nomeado para cargo de provimento efetivo em 
virtude de concurso público, após o decurso do prazo de três anos de efetivo exercício (estágio probatório), tem garantida a estabilidade no serviço público, vindo a perder o cargo somente em virtude de sentença judicial (com trânsito em julgado), de processo administrativo ou ainda por causa de procedimento de avaliação periódica de desempenho ( $\$ 1^{\circ}$ do artigo 41 da CR/88).

Todavia, embora impeça que o agente seja excluído dos quadros de pessoal da Administração Pública, a estabilidade ventilada pelo artigo 41 da CR/88 não tem o condáo de tolher alteraçóes na arquitetura organizacional da máquina administrativa.

Ora, os cargos públicos são criados e organizados com a finalidade de atender necessidades específicas da coletividade, tendo por parâmetros o momento histórico, político e social que a permeiam. São, por essa razão, instrumentos para a boa consecução de serviços públicos, conforme desde há muito tempo amestra José Cretella Júnior: "cargo público consubstancia programas a serem cumpridos pelos agentes para o atendimento do interesse público" (1999, p. 155). Porém, no eventual desaparecimento de tais necessidades, o suporte jurídico que amparava a conservação de toda uma categoria de servidores públicos deixará simultaneamente de existir.

A propósito, concludentemente afirma José dos Santos Carvalho Filho que "a estabilidade náo protege o servidor contra a extinçáo do cargo, porque nesta se presume o interesse maior da Administraçäo" (2013, p. 733). Outrossim, na mesma linha de raciocínio, segue Supremo Tribunal Federal, por meio da súmula n. 22: o estágio probatório não protege o funcionário contra a extinção do cargo (atente-se para a data de publicação do enunciado: Sessão Plenária de 13.12.1963).

Destarte, sobrevindo vicissitudes capazes de esvaziar as atribuiçóes de certos cargos públicos, torna-se necessário equacionar o interesse público, cujo desígnio é a respectiva extinção ou declaração da desnecessidade, e o interesse dos titulares desses cargos, que com fundamento no artigo $41 \mathrm{da} C R / 88$, possuem estabilidade no serviço público.

A solução intermediária providenciada pelo legislador constituinte recaiu sobre o cálculo dos vencimentos: para não gerar o enriquecimento sem causa do agente público (uma vez que não há exercício tangível da função pública), a remuneração durante o período da disponibilidade é concedida com suporte no tempo de serviço prestado, ou seja, os vencimentos passam a ser, forçosamente, proporcionais ao tempo de serviço.

Repisa-se, nessa contextura, que a essência da disponibilidade não é de viés sancionatório. Antes, constitui-se ato jurídico de justa medida que irradia efeitos na esfera patrimonial do servidor com fundamentação adequada no princípio da Supremacia do Interesse Público sobre o Interesse Privado. 
Nesse ínterim, a mensagem deôntica extraída do $\$ 3^{\circ}$ do artigo 41 da Constituição da República tem espeque no Princípio (ou Postulado) da Razoabilidade, norma elementar que reclama o agir coerente, moderado e orientado pelo bom senso. É o que, em seguida, pretende-se demonstrar.

\section{Do Princípio da Razoabilidade. Da razoabilidade no $\$ 3^{\circ}$ do artigo $41 \mathrm{da} C R / 88$}

O Postulado da Razoabilidade é um conceito jurídico indeterminado, cujo núcleo axiológico, não obstante variável no tempo e no espaço, baseia-se nos critérios de justiça, prudência e bom senso regidos pela razão humana. $\mathrm{Na}$ seara do Direito Administrativo, a Razoabilidade é empregada como método para balizar o exercício da competência discricionária na Administração Pública.

Conquanto não se encontre expressamente previsto sob essa epígrafe na Constituição da República de 1988, a doutrina brasileira é cônsona quanto à força normativa desse princípio, que pode ser contemplado implicitamente nas entrelinhas do sistema constitucional pátrio.

De modo geral, a razoabilidade é a magnitude principiológica que determina o agir moderado e sensato, inspirado por critérios oriundos do senso comum, contrapondo-se à arbitrariedade. De acordo com Willis Santiago Guerra Filho, a razoabilidade tem função negativa, significando a máxime de "não ultrapassar o limite do juridicamente aceitável” (2001, p. 69). Celso Antônio Bandeira de Mello comunga do mesmo entendimento, afirmando que:

Enuncia-se com este princípio que a Administração, ao atuar no exercício de discrição, terá de obedecer a critérios aceitáveis do ponto de vista racional, em sintonia com o senso normal de pessoas equilibradas e respeitosas das finalidades que presidiram a outorga da competência exercida. Vale dizer: pretende-se colocar em claro que não serão apenas inconvenientes, mas também ilegítimas e, portanto, jurisdicionalmente invalidáveis, as condutas desarrazoadas, bizarras, incoerentes ou praticadas com desconsideração às situaçôes e circunstâncias que seriam atendidas por quem tivesse atributos normais de prudência, sensatez e disposição de acatamento às finalidades da lei atributiva da discrição manejada (MELLO, 2011, p. 108, grifo nosso).

Segundo o eminente jurista e professor Humberto Ávila, a razoabilidade é uma máxima plurívoca, destacando-se, em sentido técnico-jurídico, três acepções principais: 
Primeiro, a razoabilidade é utilizada como diretriz que exige a relação das normas gerais com as individualidades do caso concreto, quer mostrando sob qual perspectiva a norma deve ser aplicada, quer indicando em quais hipóteses o caso individual, em virtude de suas especificidades, deixa de se enquadrar na norma geral. Segundo, a razoabilidade é empregada como diretriz que exige a vinculação das normas jurídicas com o mundo ao qual elas fazem referência, seja reclamando a existência de um suporte empírico e adequado a qualquer ato jurídico, seja demandando uma relaçáo congruente entre a medida adotada e o fim que ela pretende atingir. Terceiro, a razoabilidade é utilizada como diretriz que exige a relação de equivalência entre duas grandezas (ÁVILA, 2005, p. 103).

Nessa esteira, a razoabilidade pode ser entendida como dever de equidade (ou dever de harmonização da norma geral com o caso individual), como dever de congruência (ou dever de harmonização do direito com suas condiçóes externas) ou ainda como dever de equivalência (ou dever de vinculação entre duas grandezas).

Basicamente, a razoabilidade como dever de equidade provoca duas interferências, quais sejam: $(i)$ a presunção de que as particularidades do caso concreto se enquadram nos padróes de normalidade; e (ii) se tais particularidades se revelam extraordinárias, o aspecto individual suplanta a previsão legal genérica. Em outras palavras, o dever de congruência determina o ajustamento do direito abstratamente concebido ao caso concreto.

Em primeiro lugar, a razoabilidade impóe, na aplicação das normas jurídicas, a consideração daquilo que normalmente acontece. [...]. A razoabilidade atua como instrumento para determinar que as circunstâncias de fato devem ser consideradas com a presunção de estarem dentro da normalidade. A razoabilidade atua na interpretação dos fatos descritos em regras jurídicas. A razoabilidade exige determinada interpretação como meio de preservar a eficácia de princípios axiologicamente sobrejacentes. Interpretação diversa das circunstâncias de fato levaria à restrição de algum princípio constitucional, como o princípio do devido processo legal, nos casos analisados. Em segundo lugar, a razoabilidade exige a consideração do aspecto individual do caso nas hipóteses em que ele é sobremodo 
desconsiderado pela generalização legal. Para determinados casos, em virtude de determinadas especificidades, a norma geral não pode ser aplicável se pro tratar de caso anormal. [...]. Essas considerações levam à conclusão de que a razoabilidade serve de instrumento metodológico para dizer que a incidência da norma é condição necessária, mas nâo suficiente para sua aplicação. Para ser aplicável, o caso concreto deve adequar-se à generalização da norma geral. A razoabilidade atua na interpretaçáo das regras gerais como decorrência do princípio da justiça (preâmbulo e o art. $3^{\circ}$ da Constituição Federal) (ÁVILA, 2005, p. 103, 105).

De outra sorte, a razoabilidade enquanto dever de congruência reclama a existência de um liame entre a norma jurídica e a realidade social subjacente, de modo que para sua escorreita interpretação é imprescindível a execução de um confronto com os parâmetros que lhes são extrínsecos. Ávila explica que, como dever de congruência, a razoabilidade acarreta a necessária existência de vínculo entre a norma jurídica e o mundo ao qual ela faz referência:

A razoabilidade como dever de harmonização do Direito com suas condições externas (dever de congruência) exige a relação das normas com suas condiçốes externas de aplicação, quer demandando um suporte empírico existente para a adoção de uma medida, quer exigindo uma relação congruente entre o critério de diferenciação escolhido e a medida adotada (ÁVILA, 2005, p. 110).

Por fim, a razoabilidade na qualidade de dever de equivalência demanda a justa simetria entre a providência a ser empregada e o fim que é pretendido. Para Ávila, o dever de equivalência designa a inafastável proporção entre a mediada adotada e o critério que a dimensiona, sendo medida e critério, nessa relação, grandezas necessariamente vinculadas. $\mathrm{O}$ exemplo mais comum na literatura para essa tipologia é a dosimetria da pena em relaçáo a culpabilidade do agente: o quantum da pena deve corresponder à culpa aferida.

A razoabilidade como dever de vinculação entre duas grandezas (dever de equivalência), semelhante à exigência de congruência, impóe uma relação de equivalência entre a medida adotada e o critério que a dimensiona. Nessas hipóteses exige-se uma relação entre critério e medida, e não entre meio e fim (ÁVILA, 2005, p. 111). 
Ainda de acordo com o proeminente autor, "a razoabilidade estrutura a aplicação de outras normas, princípios e regras, notadamente das regras” (ÁVILA, 2005, p. 102).

Nesse contexto, o parágrafo $3^{\circ}$ do artigo 41 da Constituição da República assenta-se no especialmente no dever de congruência e no dever de equivalência. Senão, vejamos.

A remuneração com suporte no tempo de serviço prestado, como visto alhures, não decorre de qualquer punibilidade, antes advém do sopesamento de uma série de fatos que repercutem na situação funcional do servidor face à Administração Pública. Entre tais fatos, destacam-se: (i) o direito fundamental de estabilidade do servidor (art. 41, caput, da CR/88); (ii) a impraticabilidade de prestação de serviços (pois extinto ou declarado desnecessário o cargo); e (iii) vedação ao enriquecimento sem causa (aplicável tanto para o agente público, como para o Estado).

Destarte, inexiste desconformidade entre a disponibilidade e o vencimento proporcional. Inegável que o Direito, nesse caso, harmonizou-se com suas condiçóes externas de aplicação, mormente considerando a inexequibilidade fática de executar o serviço público e a impossibilidade jurídica de conferir, a quem quer que seja, condiçôes para enriquecer-se sem causa. Atendido, portanto, o dever de congruência.

Ademais, o preceito constitucional também congloba o dever de equivalência, cuja estrutura essencial é a ponderação entre o meio adotado e a finalidade a ser atingida. $\mathrm{O}$ meio adotado (remuneraçáo proporcional ao tempo de serviço) preserva a estabilidade (finalidade da norma estampada no caput do art. 41 da CR/88), ao mesmo tempo em que garante o interesse público. Logo, há equivalência entre a medida adotada e o critério que a dimensiona.

\section{Da viabilidade jurídica da percepçáo parcial de salários, remuneração ou subsídio para servidores afastados cautelarmente do exercício da função}

$\mathrm{Na}$ atual arquitetura constitucional, principalmente considerando as alteraçóes promovidas no texto pela Emenda Constitucional n. 19/98, o parágrafo único do artigo 20 da Lei de Improbidade Administrativa náo é razoável, conforme passa-se a expor.

Dispóe o artigo 20 da Lei de Improbidade Administrativa que:

Art. 20. A perda da função pública e a suspensão dos direitos políticos só se efetivam com o trânsito em julgado da sentença condenatória. 


\section{Parágrafo único. A autoridade judicial ou administrativa competente poderá determinar o afastamento do agente público do exercício do cargo, emprego ou função, sem prejuízo da remuneração, quando a medida se fizer necessária à instrução processual (BRASIL, 1992).}

O afastamento do agente público, na hipótese, detém natureza processual com nítida feição cautelar, com finalidade precipuamente probatória, cujo deferimento exige a demonstração concomitante da "aparência do direito" (fumus boni iuris) e do "perigo na demora" (periculum in mora), a partir da exposição de evidências que espelham possível atuação perniciosa do agente público, prejudicando a instrução probatória.

Há certo consenso que a expressão "sem prejuízo da remuneração" determina que, durante o afastamento, os vencimentos sejam integralmente pagos, como se em atividade estivesse o servidor público. Todavia, é necessário conferir ao parágrafo único do artigo 20 uma releitura baseada no Princípio da Razoabilidade.

Recordemo-nos que as palavras iniciais desse modesto esboço foram dedicadas a apreciar, ainda que brevemente, a situação jurídica do servidor público posto em disponibilidade, nos termos do artigo $41, \$ 3^{\circ}$, da CR/88. Nesse caso, em que não se vislumbra medida sancionatória, perceberá o agente público remuneração proporcional ao tempo de serviço.

Por outro lado, ao servidor afastado por decisão cautelar, em prol da instrução processual relacionada a possível prática de ato de improbidade administrativa, é garantida a remuneração integral. Embora nesse último caso também não se verifique quaisquer objetivos sancionatórios, não se pode negar que sobre a conduta do servidor recaiu juizo de reprovabilidade, pelo menos no que diz respeito à potencialidade de causar embaraços à instrução processual, o que inexiste no primeiro caso.

É necessário considerar, ainda, que a possibilidade de afastamento liminar do agente público do exercício do cargo, emprego ou função, é considerando pelo Superior Tribunal de Justiça como medida extrema, pelo que se exige prova de que a permanência do servidor pode ensejar dano efetivo à instrução processual. Nesse sentido: Recurso Especial n. 929.483/BA. Rel. Ministro Luiz Fux. Primeira Turma. Julgado em 02/12/2008. DJe 17/12/2008.

Ora, tendo em vista que o afastamento do servidor público, na condição do parágrafo único do artigo 20 da Lei de Improbidade Administrativa, decorre da burla ao dever de lealdade institucional e a observância dos princípios que orientam a Administração Pública (a respeito do qual, reitera-se, imprescinde de prova) é correto concluir que houve contribuiçáo contraproducente desse para a razão que motiva o afastamento. 
Confrontando o afastamento do servidor público em casos de disponibilidade (art. $41, \mathbb{S} 3^{\circ}$, da $\mathrm{CR} / 88$ ) e nos casos de afastamento cautelar quando a medida se fizer necessária à instrução processual (art. 20, parágrafo único, da Lei n. 8.429/1992), é possível perceber a falta de razoabilidade nesta disposição.

$\mathrm{Na}$ disponibilidade (art. 41, $\$ 3^{\circ}$, da $\mathrm{CR} / 88$ ) não paira sobre o servidor nem mesmo a suspeita de prática de atos que, de algum modo, causem prejuízos à Administração Pública. De todo modo, a disponibilidade inegavelmente irradiará efeitos na esfera patrimonial do agente público. Como visto, a fundamentação baseia-se no princípio da Supremacia do Interesse Público sobre o Interesse Privado e no Princípio da Razoabilidade.

O afastamento, que também não se trata de sanção, é uma medida de caráter cautelar, preventiva, sem caráter punitivo e temporária, assemelhando-se, nesses aspectos, à disponibilidade.

Sendo assim, há duas situações similares, com soluçóes jurídicas opostas: (i) servidor público posto em disponibilidade e com percepção proporcional ao tempo de serviço até o reaproveitamento; e (ii) servidor afastado por decisão judicial, quando imprescindível à instrução processual (art. 20, parágrafo único, da Lei n. 8.429/92), com remuneração integral.

A despeito de em ambos os casos náo se vislumbrarem quaisquer objetivos sancionatórios - conforme repetidas vezes já dito -, diga-se, novamente, que sobre a conduta do servidor afastado recaiu juízo de reprovabilidade, o que inexiste no primeiro caso. Espantosamente, a solução jurídica mais vantajosa (recebimento integral de vencimentos) é deferida ao servidor afastado com fundamento no art. 20, parágrafo único, da Lei n. 8.429/92.

Ora, como admitir que tais situaçôes convivam no mesmo sistema jurídico? No cotejo, percebe-se que a solução jurídica conferida pelo parágrafo único do art. 20 da Lei n. 8.429/92 é flagrantemente desarrazoada, já que não atende nem ao dever de congruência, nem o dever de equidade, conforme visto outrora.

Não se olvida que, quando do advento da Lei de Improbidade Administrativa, em 1992 , vigorava a redaçáo original do art. $41, \$ 3^{\circ}$, da $\mathrm{CR} / 88$, entendendo-se que na disponibilidade deferia-se o pagamento integral da remuneração ao posto em disponibilidade. Ocorre que, passados mais de 26 (vinte e seis) anos desde a sua homologação e 25 (vinte e cinco) anos de vigência, alterado o texto constitucional em situaçôes semelhantes, é imperioso que se confira ao dispositivo interpretação conforme a Constituição.

Quando editada a Lei n. 8.429, em 1992, o cenário jurídico, político, social e econômico do país era outro, muito diverso do que atualmente se observa. Se na época de sua publicação a interpretação literal se justificava, hoje não é mais 
possível persistir na defesa de sua autoridade, porque se tornou incompatível com a Constituição com o decorrer do tempo e com as mudanças na sociedade brasileira.

Assim, embora o artigo 20, parágrafo único, outrora fosse harmônico com a Constituiçẫo da República de 1988, fato é que, com o tempo, tornou-se antagônico. Desse modo, é imperioso equalizar o comando legal para que, em sintonia com as demais disposiçóes do sistema jurídico, especialmente as determinaçóes constitucionais, preservem-se simultaneamente o Interesse Público (e também o Patrimônio Público) e os direitos e garantias dos servidores públicos civis.

Em arremate, conclui-se que a percepção parcial de remuneração representa, tanto nas hipóteses do art. $41, \$ 3^{\circ}$, da $C R / 88$, como do art. 20 , $\$$ único, da Lei n. 8.429/1992, o ponto ótimo entre a Supremacia do Interesse Público (que engloba, e.g., o direito fundamental à boa administração e à moralidade administrativa) e o direito à contraprestação financeira que faz jus o servidor afastado do cargo.

\section{Consideraçóes finais}

Diante do todo exposto, é possível arrematar que a literalidade do artigo 20, parágrafo único, da Lei n. 8.429/1992 deve ser interpretado não em sua literalidade, mas em conformidade com a atual arquitetura constitucional. É necessário fazer valer, nesse aspecto, o brocardo "ubi eadem ratio, ibi eadem legis dispositio" ou, em vernáculo, "onde existe a mesma razão fundamental, prevalece a mesma regra de Direito".

O instituto da disponibilidade (artigo 41, parágrafo $3^{\circ}$, da Constituição da República de 1988) e o afastamento cautelar (art. 20, $\$$ único, da Lei $n$. $8.429 / 1992)$ se assemelham por não constituir penalidade administrativa. Todavia, se distanciam quanto a solução jurídica ofertada.

É que, para a promoção do afastamento cautelar, é imprescindível a existência de indícios (ou, de acordo com o Superior Tribunal de Justiça, de provas) da burla ao dever de lealdade institucional do servidor, cuja conduta contraproducente obstaculiza efetivamente a instrução processual. Recai sobre o agente público juízo de reprovabilidade, pelo menos em relação a seu comportamento no decorrer da coleta probatória.

Esse aspecto evidencia a disparidade entre a disponibilidade e o afastamento cautelar. $\mathrm{Na}$ disponibilidade (art. $41, \S 3^{\circ}$, da $\mathrm{CR} / 88$ ) náo paira sobre o servidor nem mesmo a suspeita de prática de atos que, de algum modo, causem prejuízos à Administração Pública. Mesmo assim, inegavelmente irradiará efeitos na esfera patrimonial do agente público. Como visto, a fundamentaçáo baseia-se 
no princípio da Supremacia do Interesse Público sobre o Interesse Privado e no Princípio da Razoabilidade.

Sem embargo, no afastamento cautelar, o servidor náo prestará serviços (em razão, repisa-se, de seu comportamento reprovável durante o período de instrução probatória) e receberá a remuneração integral, conforme a interpretação comumente deferida. Ora, não há razoabilidade. Vide que as mesmas justificativas empregadas para respaldar a disponibilidade (quais sejam, o direito fundamental de estabilidade do servidor; a impraticabilidade de prestação de serviços; vedação ao enriquecimento sem causa), as quais demonstram sua razoabilidade, podem perfeitamente ser aproveitadas para o afastamento cautelar - o que, diga-se em arremate, apresentaria um teor de justiça maior, haja vista que nesses casos o servidor público contribui, negativamente, para a adoção da medida (o que não se vê na disponibilidade).

\section{Referências}

ÁVILA, H. Teoria dos Princípios: da definição à aplicação dos princípios jurídicos. BRASIL. Constituição (1937). Constituiçāo dos Estados Unidos do Brasil. Diário Oficial da União, Rio de Janeiro, RJ, 10 nov. 1937. Disponível em: <http://www. planalto.gov.br/ccivil_03/constituicao/constituicao37.htm>. Acesso em: 8 jul. 2019.

BRASIL. Constituiçãa (1946). Constituição dos Estados Unidos do Brasil. Diário Oficial da União, Rio de Janeiro, RJ, 19 set. 1946. Disponível em: <http://www. planalto.gov.br/ccivil_03/constituicao/constituicao46.htm $>$. Acesso em: 8 jul. 2019.

BRASIL. Constituição (1967). Constituição da República Federativa do Brasil. Diário Oficial [da] República Federativa do Brasil, Brasília, DF, 24 jan. 1967. Disponível em: <http://www.planalto.gov.br/ccivil_03/constituicao/ constituicao67.htm>. Acesso em: 8 jul. 2019.

BRASIL. Constituiçáo (1967). Emenda Constitucional n. 1, de 17 de outubro de 1969. Edita o novo texto da Constituiçáo Federal de 24 de janeiro de 1967. Diário Oficial [da] República Federativa do Brasil, Braślia, DF, 20 out. 1969. Disponível em: <http://www.planalto.gov.br/ccivil_03/constituicao/emendas/ emc_anterior1988/emc01-69.htm>. Acesso em: 8 jul. 2019.

BRASIL. Constituição (1988). Constituiçăo da República Federativa do Brasil. Diário Oficial [da] República Federativa do Brasil, Brasília, DF, 5 out. 
1988. Disponível em: <http://www.planalto.gov.br/ccivil_03/constituicao/ constituicaocompilado.htm>. Acesso em: 8 jul. 2019.

BRASIL. Constituição (1988). Emenda Constitucional n. 19, de 04 de junho de 1998. Modifica o regime e dispõe sobre princípios e normas da Administração Pública, servidores e agentes políticos, controle de despesas e finanças públicas e custeio de atividades a cargo do Distrito Federal, e dá outras providências. Diário Oficial [da] República Federativa do Brasil, Brasília, DF, 06 fev. 1998. Disponível em: <http://www.planalto.gov.br/ccivil_03/Constituicao/Emendas/Emc/emc19. htm>. Acesso em: 8 jul. 2019.

BRASIL. Decreto n. 99.300, de 15 de junho de 1990. Dispóe sobre os proventos dos servidores postos em disponibilidade e dá outras providências. Diário Oficial [da] República Federativa do Brasil, Brasília, DF, 16 jun. 1990. Disponível em: <http://www.planalto.gov.br/ccivil_03/decreto/1990-1994/D99300.htm>. Acesso em: 8 jul. 2019.

BRASIL. Lei n. 8.429, de 02 de junho de 1992. Dispóe sobre as sançóes aplicáveis aos agentes públicos nos casos de enriquecimento ilícito no exercício de mandato, cargo, emprego ou função na administração pública direta, indireta ou fundacional e dá outras providências. Diário Oficial [da] República Federativa do Brasil, Brasília, DF, 03 jun. 1992. Disponível em: <http://www.planalto.gov.br/ ccivil_03/leis/18429.htm>. Acesso em: 8 jul. 2019.

BRASIL. Supremo Tribunal Federal. Ação Direta de Inconstitucionalidade n. 239. Tribunal Pleno, DF, 19 de fevereiro de 2014. Relator Ministro Dias Toffoli. Tribunal Pleno. Julgado em 19/02/2014. Disponível em: <http://redir.stf.jus.br/ paginadorpub/paginador.jsp?doc TP=TP\&docID=7065404>. Acesso em: 8 jul. 2019.

BRASIL. Supremo Tribunal Federal. Ação Direta de Inconstitucionalidade n. 313. Tribunal Pleno, DF, 21 de agosto de 1991. Relator Ministro Paulo Brossard. Tribunal Pleno. Julgado em 21/08/1991. Disponível em: <http://redir.stf.jus.br/ paginadorpub/paginador.jsp?doc $\mathrm{TP}=\mathrm{AC} \& \mathrm{doc} \mathrm{ID}=266296>$. Acesso em: 8 jul. 2019.

BRASIL. Supremo Tribunal Federal. Súmula n. 22. O estágio probatório não protege o funcionário contra a extinção do cargo. Disponível em: <http://www.stf. jus.br/portal/jurisprudencia/menuSumarioSumulas.asp?sumula $=2110>$. Acesso em: 8 jul. 2019. 
BRASIL. Supremo Tribunal Federal. Súmula n. 358. O servidor público em disponibilidade tem direito aos vencimentos integrais do cargo. Disponível em: <http://www.stf.jus.br/portal/jurisprudencia/menuSumarioSumulas. asp?sumula=2079>. Acesso em: 8 jul. 2019.

CARVALHO FILHO, J. S. Manual de Direito Administrativo. 26. ed. São Paulo: Atlas, 2013.

CRETELLA JÚNIOR, J. Filosofia do Direito Administrativo. Rio de Janeiro: Forense, 1999.

DI PIETRO, M. S. Z. Direito Administrativo. 26. ed. Sáo Paulo: Atlas, 2013.

GASPARINI, D. Direito Administrativo. 16. ed. São Paulo: Saraiva, 2011.

GUERRA FILHO, W. S. Processo constitucional e direitos fundamentais. 2. ed. São Paulo: Celso Bastos Editor, 2001.

MELLO, C. A. B. Curso de Direito Administrativo. 28. ed. São Paulo: Malheiros, 2011. 